\title{
Broccoli Production With Regulated Deficit Irrigation at Different Phenological Stages
}

\author{
Daniele de Souza Terassi ${ }^{1}$, Roberto Rezende ${ }^{1}$, Gustavo Soares Wenneck ${ }^{1}$, Cláudia Salim Lozano Menezes ${ }^{1}$, \\ André Felipe Barion Alves Andrean ${ }^{1}$, Vinícius Villa e Vila ${ }^{1} \&$ Lucas Henrique Maldonado da Silva ${ }^{1}$ \\ ${ }^{1}$ Post-graduate in Agronomy, State University of Maringá, Paraná, Brazil \\ Correspondence: Daniele de Souza Terassi, Post-graduate in Agronomy, State University of Maringá, Avenue \\ Colombo 5790, Maringá, Paraná, Brazil. Tel: 55-44-3011-8940. E-mail: daniele_terassi@hotmail.com
}

Received: October 7, 2021

doi:10.5539/jas.v13n12p71

\author{
Accepted: October 31, $2021 \quad$ Online Published: November 15, 2021 \\ URL: https://doi.org/10.5539/jas.v13n12p71
}

\begin{abstract}
The objective of this study was to evaluate the effects of different levels of soil water replacement in each phenological stage of broccoli crop cultivated in a protected environment. The experiment was conducted in a protected environment in the municipality of Maringá, Paraná, Brazil. The experimental design used was in randomized blocks 4 by 3 having four levels of water replacement $(55,70,85$, and $100 \%$ of crop evapotranspiration) applied in three phenological stages (initial, intermediate, and final), and four replications. Productivity, inflorescence fresh matter, leaf fresh matter, stem fresh matter, number of leaves, stem diameter, inflorescence height, inflorescence diameter, plant height, leaf area, inflorescence dry matter, stem dry matter and leaf dry matter were evaluated. The data were submitted to variance analysis and compared by Scott-Knott test and regression analysis. Deficit of $30 \%$ of the ETc during the final stage of the broccoli crop, reduced productivity by $7 \%$, on the other hand for the initial and intermediate stages, there was a drop of $30 \%$ and $23 \%$ respectively. The water deficit caused significant losses in broccoli production during the first phenological stages, but the final stage was less critical.
\end{abstract}

Keywords: Brassica oleracea var. italica, water management, irrigation

\section{Introduction}

Broccoli (Brassica oleracea var. italica) presents lateral inflorescences (ramoso type) or compact central inflorescence (single head), both of dark green coloration, consisting of water $(90.7 \%)$, proteins, calcium and vitamins A, B and C (Rodrigues et al., 2013). In Brazil, the cultivation of single-headed broccoli is increasing with expansion associated with the frozen food segment (Schiavon et al., 2015).

Broccoli culture demands up to $4.1 \mathrm{~mm} \mathrm{day}^{-1}$ (Kumari et al., 2018). It is essential to quantify the crop's water requirement to increase production efficiency and product quality, especially during the formation of inflorescence (Schiavon et al., 2015).

Regulated deficit irrigation (RDI) is one of the main techniques of water saving in agriculture (Chai et al., 2014), promoting improvement in the efficiency of use and net profit obtained by farmers (Nora et al., 2012; Wenneck et al., 2021).

The cultivated plants response to water stress varies at different stages of growth, the stability in productivity is possible with the adoption of moderate stress (Hachmann et al., 2019). The availability and use of water have serious socioeconomic and political consequences, technical development and management are necessary to reduce or mitigate the effects of water stress in plants (Chai et al., 2014).

Water management in irrigated agriculture, considering the rational use of water resources, allows greater resource efficiency during the production process (Santos et al., 2018a). Considering the requirement of using water efficiently, the objective of this study was to evaluate the effects of different levels of soil water replacement in each phenological stage of broccoli crop cultivated in a protected environment.

\section{Method}

The experiment was conducted in a protected environment at the Technical Irrigation Center (CTI) belonging to the State University of Maringá (UEM) located in the municipality of Maringá, Paraná, Brazil $\left(23^{\circ} 25^{\prime} \mathrm{S}, 51^{\circ} 57^{\prime} \mathrm{W}\right.$ 
and $542 \mathrm{~m}$ altitude). The climate, classified according to Koppen, is of the subtropical mesothermal humid type, with annual average precipitation of $1500 \mathrm{~mm}$ and average value for temperature close to 28 to $29^{\circ} \mathrm{C}$ (Nitsche et al., 2019). The protected environment features arched ceiling, coated with low density polyethylene film (150 $\mu \mathrm{m}$ thick) and protected sides with white anti-fid screen.

A randomized block design was used in a $4 \times 3$ factorial scheme, with four levels of water replacement $(55,70$, 85 , and $100 \%$ of crop evapotranspiration (ETc)) applied in three phenological stages (initial stage: from planting to 7 to 10 leaves; intermediate stage: from 7 to 10 leaves until the inflorescence appearance in the meristem; final stage: from the inflorescence emergence to harvest), with four replications. Phenological stages were defined according to Allen et al. (1998).

Broccoli seedlings, hybrid BRO 68 ${ }^{\circledR}$, produced in polystyrene trays ( 200 cells) with coconut fiber substrate, and housed in a greenhouse until transplantation. Transplanting for definitive site was performed when the seedlings presented three to four definitive leaves, with spacing of $1.0 \mathrm{~m}$ between row and $0.5 \mathrm{~m}$ between plants. The experimental unit consisted of six plants and the two central plants were evaluated.

The soil of the experimental area is classified as Nitossolo Vermelho distroférrico correlated with Ultisol in the soil taxonomy classification (Santos et al., 2018b). A composite sample was collected at a depth of $0-20 \mathrm{~cm}$ for chemical characterization of the soil (Table 1).

Table 1. Soil chemical analysis.

\begin{tabular}{|c|c|c|c|c|c|c|}
\hline $\mathrm{pH} \mathrm{CaCl}{ }_{2}$ & $\mathrm{pH}$ SMP & O.M. & $\mathrm{C}$ & $\mathrm{P}$ & $\mathrm{K}$ & $\mathrm{Ca}^{2+}$ \\
\hline & & \multicolumn{2}{|c|}{ - $\mathrm{g} \mathrm{dm}^{-3}$} & $\mathrm{mg} \mathrm{dm} \mathrm{m}^{-3}$ & \multicolumn{2}{|c|}{ - $\mathrm{cmol}_{\mathrm{c}} \mathrm{dm}^{-3}$} \\
\hline 6.60 & 7.10 & 20.13 & 11.68 & 69.13 & 0.51 & 6.43 \\
\hline $\mathrm{Mg}^{+2}$ & $\mathrm{Al}^{+3}$ & $\mathrm{H}^{+} \mathrm{Al}^{3+}$ & SB & CEC & $\mathrm{V}$ & B \\
\hline \multicolumn{7}{|c|}{ 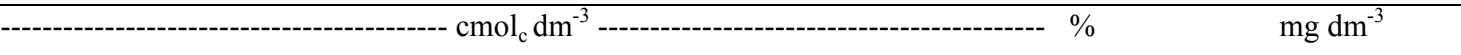 } \\
\hline 1.87 & 0 & 2.12 & 8.81 & 10.93 & 80.60 & 0.37 \\
\hline $\mathrm{Cu}$ & $\mathrm{Zn}$ & $\mathrm{Fe}$ & $\mathrm{Mn}$ & & & \\
\hline \multicolumn{7}{|c|}{ 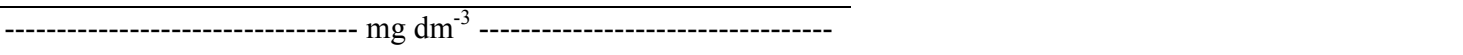 } \\
\hline 14.34 & 9.36 & 78.42 & 119.10 & & & \\
\hline
\end{tabular}

Note. O.M.: organic matter; CEC: cation exchange capacity.

Soil preparation was carried out with rotating hoe, and 48 plants beds of $3.0 \mathrm{~m}$ long and $0.5 \mathrm{~m}$ wide were later built. $60 \mathrm{~kg} \mathrm{ha}^{-1}$ nitrogen (urea), $200 \mathrm{~kg} \mathrm{ha}^{-1}$ phosphorus (simple superphosphate) and $120 \mathrm{~kg} \mathrm{ha}^{-1}$ potassium (potassium chloride) were applied based on soil analysis and recommendations for culture (Pauletti \& Motta 2017).

The Penman-Monteith method, standardized by FAO according to Allen et al. (1998), was used to estimate the reference evapotranspiration (ETo), using weather station data present inside the protected environment. The crop coefficients of 0.7 (initial stage), 1.05 (intermediate stage) and 0.95 (final stage) were used to determine crop evapotranspiration.

Water replacement was performed every two days at 8 o'clock. The irrigation system used was drip microirrigation, containing in each site 10 self-compensating flow drippers $4 \mathrm{~L} \mathrm{~h}^{-1}$ spaced at $0.25 \mathrm{~m}$ and operating at a pressure of $100 \mathrm{kPa}$. During 14 days after transplanting (DAT), 100\% of the ETc was redone for the establishment of the crop. Pest control was performed with deltamethrin $\left(25 \mathrm{~g} \mathrm{~L}^{-1}\right)$ according to recommendations for the culture. Weeds were manually controlled.

At 81 DAT, the stem diameter, number of leaves and plant height were determined in the field. The plants sectioned near the soil surface and sent to the laboratory to determine the diameter and height of the inflorescences, inflorescence fresh matter, stem fresh matter and leaf fresh matter. The inflorescence dry matter, stem dry matter and leaf dry matter was determined after samples were submitted in a forced air circulation oven at $65^{\circ} \mathrm{C}$ until reaching constant weight. The leaf area was determined using the LI-3100 equipment. Crop yield was estimated in $\mathrm{kg} \mathrm{m}^{-2}$.

The data were submitted to variance analysis, being compared by the Scott-Knott test and regression analysis with 5\% significance, using the statistical software SISVAR (Ferreira, 2019). 


\section{Results and Discussion}

Table 2 shows the duration of the phenological stages, the longest was the initial stage resulting in a longer period of exposure to water deficit.

Table 2. Duration of phenological stages of broccoli culture

\begin{tabular}{llcl}
\hline Phenological stage & Start & Final & Duration \\
\hline & -------------- & DAT --------------- & days \\
Initial & 15 & 40 & 25 \\
Intermediate & 41 & 61 & 20 \\
Final & 62 & 81 & 19 \\
\hline
\end{tabular}

The variables productivity, inflorescence fresh matter, leaf fresh matter, inflorescence diameter, plant height, leaf area, inflorescence dry matter and leaf dry matter of broccoli crop were influenced by applied water depths, it was possible to adjust quadratic regression models, significant at the level of $5 \%$ probability as shown in Figure 1. 

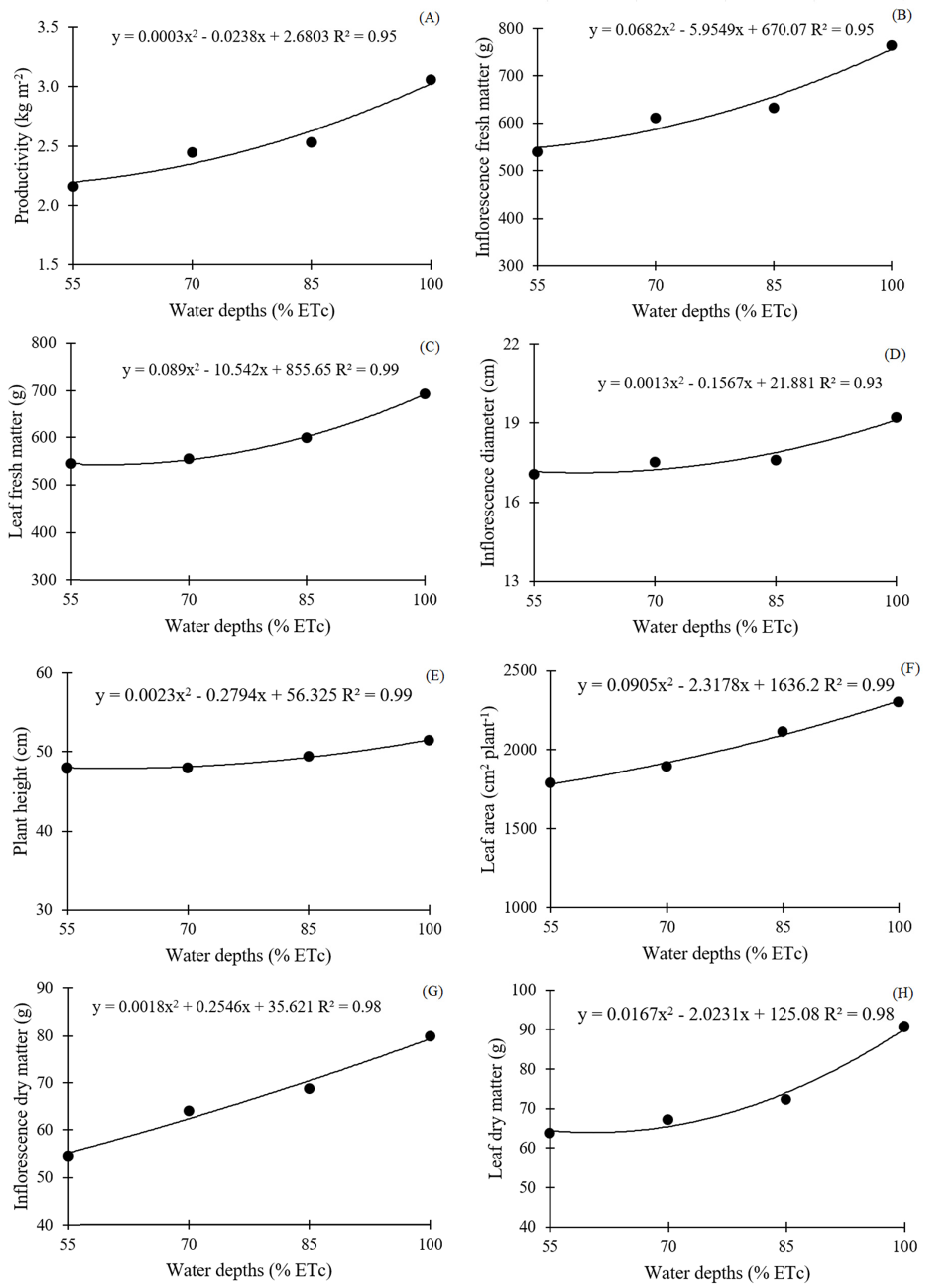

Figure 1. Productivity (A), inflorescence fresh matter (B), leaf fresh matter (C), inflorescence diameter (D), plant height $(E)$, leaf area $(F)$, inflorescence dry matter $(\mathrm{G})$ and leaf dry matter $(\mathrm{H})$ for broccoli crop as a function of water depths 
The increase of water depths provided increased productivity, inflorescence fresh matter, leaf fresh matter, inflorescence diameter, plant height, leaf area, inflorescence dry matter and leaf dry matter (Figure 1). According to Taiz et al. (2017) the most prominent response of plants to water deficit, is the decrease in leaf area production, stomata closure, acceleration of senescence and leaf abscisc, culminating in decreased production. Although mechanisms such as the decrease in stomatic conductance, help in the maintenance of turgor, they lead to the reduction of gas exchange of the plant, reducing the photosynthetic rates and, consequently, the accumulation of fresh and dry matter (Nawaz et al., 2015).

According to Figure 1, the highest productivity value was obtained with a replacement of $100 \%$ of the ETc with a yield of $3.06 \mathrm{~kg} \mathrm{~m}^{-2}$, it was $30 \%$ higher than that obtained with a replacement of $55 \%$ of the ETc. Similar results were reported by Ayas et al. (2011), when irrigation depths of 75 and $100 \%$ of ETc were applied to broccoli culture, the obtained values were 2.75 and $2.92 \mathrm{~kg} \mathrm{~m}^{-2}$, respectively.

Tangune et al. (2016) observed that the highest yield value of single-head broccoli production was $2.65 \mathrm{~kg} \mathrm{~m}^{-2}$ when irrigations were performed at the strain of $15 \mathrm{kPa}$ at $0.2 \mathrm{~m}$ depth. Deficit irrigation causes a reduction in yield according to the stress level that the plant is subjected to (Hachmann et al., 2019; Wenneck et al., 2021).

Erdem et al. (2010) reported a maximum marketable yield of $0.81 \mathrm{~kg} \mathrm{~m}^{-2}$ when broccoli irrigation with $50 \%$ of ETc and an irrigation interval of 7 days. Silveira et al. (2016) evaluating the production of branchy broccoli submitted to different levels of soil water replacement, obtained the highest productivity of $0.46 \mathrm{~kg} \mathrm{~m}^{-2}$ with replacement of $100 \%$ of ETc. These yield differences can be attributed to several factors, including differences of cultivars, climatic conditions, management methods adopted and regions.

The morphological variables of broccoli culture were influenced by the differentiation of phenological stages, and it was possible to apply the Scott-Knott test at the level of 5\% probability, as shown in Table 3.

Table 3. Components of broccoli culture as a function of phenological stage

\begin{tabular}{|c|c|c|c|c|c|c|}
\hline Phenological stage & PROD & IFM & LFM & ID & $\mathrm{PH}$ & LDM \\
\hline & $\mathrm{kg} \mathrm{m}^{-2}$ & \multicolumn{2}{|c|}{------------- kg ------------ } & \multicolumn{2}{|c|}{------------- m ------------ } & $\mathrm{kg}$ \\
\hline Initial & $2.406 \mathrm{~b}$ & $0.601 \mathrm{~b}$ & $0.598 \mathrm{~b}$ & $0.171 \mathrm{~b}$ & $0.490 \mathrm{~b}$ & $0.069 \mathrm{~b}$ \\
\hline Intermediário & $2.540 \mathrm{~b}$ & $0.635 \mathrm{~b}$ & $0.578 \mathrm{~b}$ & $0.181 \mathrm{a}$ & $0.485 \mathrm{~b}$ & $0.071 \mathrm{~b}$ \\
\hline Final & $2.701 \mathrm{a}$ & $0.675 \mathrm{a}$ & $0.619 \mathrm{a}$ & $0.184 \mathrm{a}$ & $0.502 \mathrm{a}$ & $0.080 \mathrm{a}$ \\
\hline
\end{tabular}

Note. * Means followed by the same letter in the column don't differ from each other by the Scott-Knott test ( $\mathrm{p} \geq$ 0.05). PROD: productivity; IFM: inflorescence fresh matter; LFM: leaf fresh matter; ID: inflorescence diameter; PH: plant height; LDM: leaf dry matter.

Productivity was influenced by phenological stage (Table 3 ). The final stage presented average productivity of $2.70 \mathrm{~kg} \mathrm{~m}^{-2}$ being significantly higher than the initial stage $\left(2.41 \mathrm{~kg} \mathrm{~m}^{-2}\right)$ and intermediate stage $\left(2.54 \mathrm{~kg} \mathrm{~m}^{-2}\right)$. There was a significant effect of water depths for the three phenological stages, the increase in water deficit tends to reduce productivity (Figure 2). 


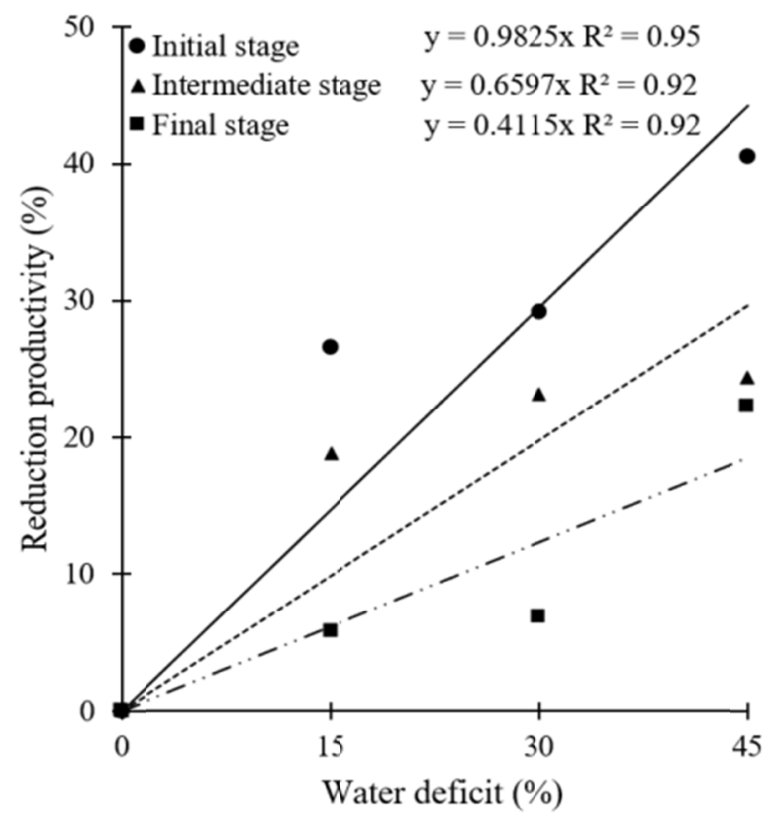

Figure 2. Reduction productivity in broccoli as a function of water depths for the three phenological stages

The increase in water deficit caused a smaller reduction in productivity during the final stage, and the deficit of $30 \%$ of the ETc in the final stage of broccoli culture resulted in a $7 \%$ decrease in productivity (Figure 2). Water stress can generate a passive adaptation of plants in a condition of water scarcity, however when the deficit occurs in a regulated way with targeted irrigation treatment can cause improvement in the quality of agricultural production and in the efficiency of water use (Du et al., 2015).

Kuşçu et al. (2014) observed in the tomato crop that the interruption of full irrigation after the beginning of the ripening stage of the fruits can be recommended, as it provided water savings of $33 \%$ with a loss of yield of $5 \%$.

The effects of deficit irrigation on melon (Cucumis melo L.) also depend on the time of deficit imposition. In 'piel del sapo' melon hybrid, yield was reduced when deficits were applied during flowering (Fabeiro et al., 2002).

In the garlic crop (Allium sativum L.) the deficit irrigation showed an effect on yield when applied during the ripening stage, and when applied at the bulification stage decreased yield and quality of the bulb (Cortés et al., 2003). Carvalho et al. (2004) analyzing different levels of water repositions in eggplant culture in different phenological stages, obtained lower productivity in the fruit formation phase.

The references prove, the period of imposition of water deficit causes changes in crop growth and yield, not only for broccoli but also for other vegetables.

The limitation in the availability of water in the soil during the pre-flowering period affects the development of plant vegetative structures, reducing the production capacity of phytomass by the crops (Chai et al., 2016).

The behavior of phenological stages within each water depths, referring to productivity, a significant effect of the phenological stage was obtained for the replacement of the water depths of 55, 70 and $85 \%$ of the ETc. The final stage productivity was significantly higher than the initial and intermediate stages for the water depths of 70 and $85 \%$, while in the water depth of $55 \%$ the intermediate and final stages were significantly higher than the initial stage. This finding suggests that the final stage was the least sensitive to water deficit.

The inflorescence fresh matter increased with the elevation of the water depths. In the water depth referring to $100 \%$ of ETc, the mean value of the IFM was $0.764 \mathrm{~kg}$ (Figure 1). The phenological stage also influenced the IFM of broccoli, and in the final stage the mass $(0.675 \mathrm{~kg})$ was significantly higher than the obtained in the initial and intermediate stages with $0.601 \mathrm{~kg}$ and $0.635 \mathrm{~kg}$, respectively (Table 3). Silva, Biscaro, Oliveira et al. (2019) when evaluating the productive characteristics of fertigated broccoli with different nitrogen doses obtained similar IFM results. 
As the analyzed broccoli hybrid is the one that presents inflorescence as the only production component, the reduction inflorescence fresh matter is directly related to reduction productivity and also presents a significant effect of water depths for all phenological stages studied (Figure 2).

With an increase in water deficit during the initial and intermediate stages, there is a greater loss of the IFM than in the final stage, with a deficit of 30\% of the ETc, there was a 7\% drop in the IFM (Figure 2). Similar results were observed by Silveira et al. (2016) in which the largest mass of the floral stems of broccoli was obtained when water repositions were differentiated in the harvest phase. Miorini et al. (2011), evaluating the suppression of water in different phenological phases of common bean, confirm the greater requirement for water in the vegetative and flowering phase.

The analysis of phenological stages at each water depth, referring to the IFM, no significant effect of the phenological stage was obtained only on the $100 \%$ ETc depth. Water depths of 70 and $85 \%$ in the final stage was significantly higher. In the $55 \%$ lamina of the intermediate and final stages were significantly higher than the initial stage, and the broccoli inflorescences showed better development when the differentiation of the water depths were applied in the final stage.

The leaf fresh matter of broccoli was higher in the $100 \%$ ETc depth (Figure 1 C). The LFM of broccoli was also influenced by the phenological stage, the final stage presented $0.619 \mathrm{~kg}$ being significantly higher than the initial and final stages with $0.598 \mathrm{~kg}$ and $0.578 \mathrm{~kg}$, respectively (Table 3). Water deficit caused a significant increase in the fall of fresh leaf mass (Figure 3).

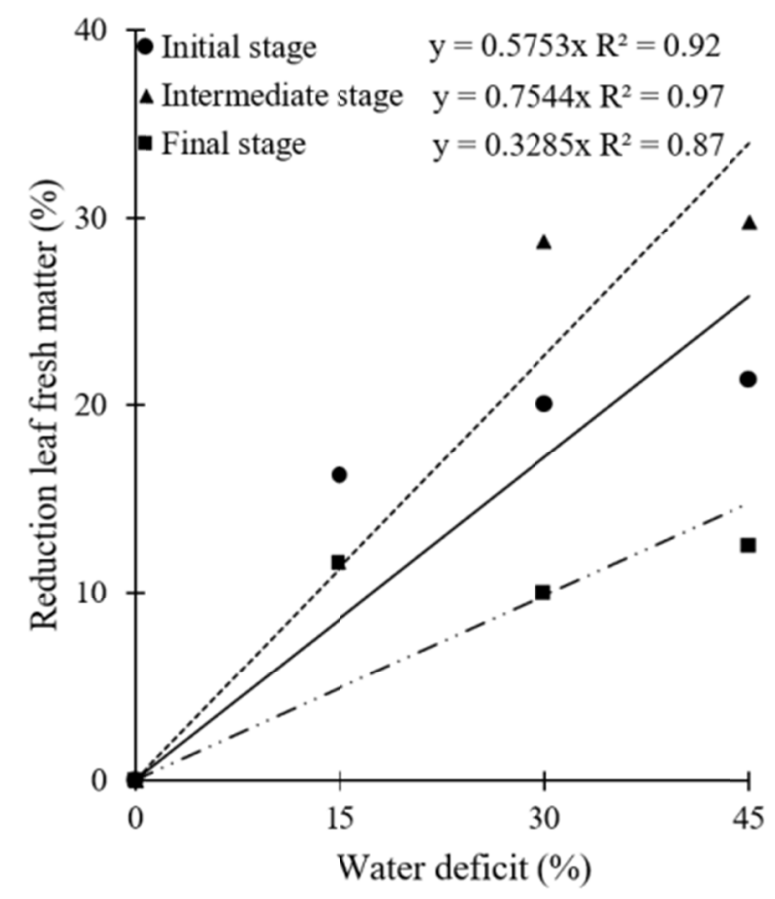

Figure 3. Reduction leaf fresh matter in broccoli as a function of water depths for the three phenological stages

In the intermediate stage, leaf fresh matter is reduced with increases the water deficit. In the final stage, the water deficit of $30 \%$ caused a $10 \%$ reduction in LFM (Figure 3).

According to Taiz et al. (2017) the decrease of water in the soil promotes the closure of the stomata, blocking the flow of $\mathrm{CO}_{2}$ to the leaves, reducing the concentration in the intracellular spaces and affecting the accumulation of photoassimilates. After the interruption of the water deficit, the parameters tend to recover, but not in their fullness because the speed of recovery is reduced.

The behavior of phenological stages within each water depth, referring to the leaf fresh matter, a significant effect of the phenological stage was observed only for the 55 and $70 \%$ of the ETc, in which the initial and final stages were superior to the intermediate stage for both depths. 
The increase in water supply provided a linear increase in the leaf area of broccoli (Figure 1). In the unfolding of the water depth and stage interaction there was a significant effect of the water depths for the initial and intermediate phenological stages (Figure 4).

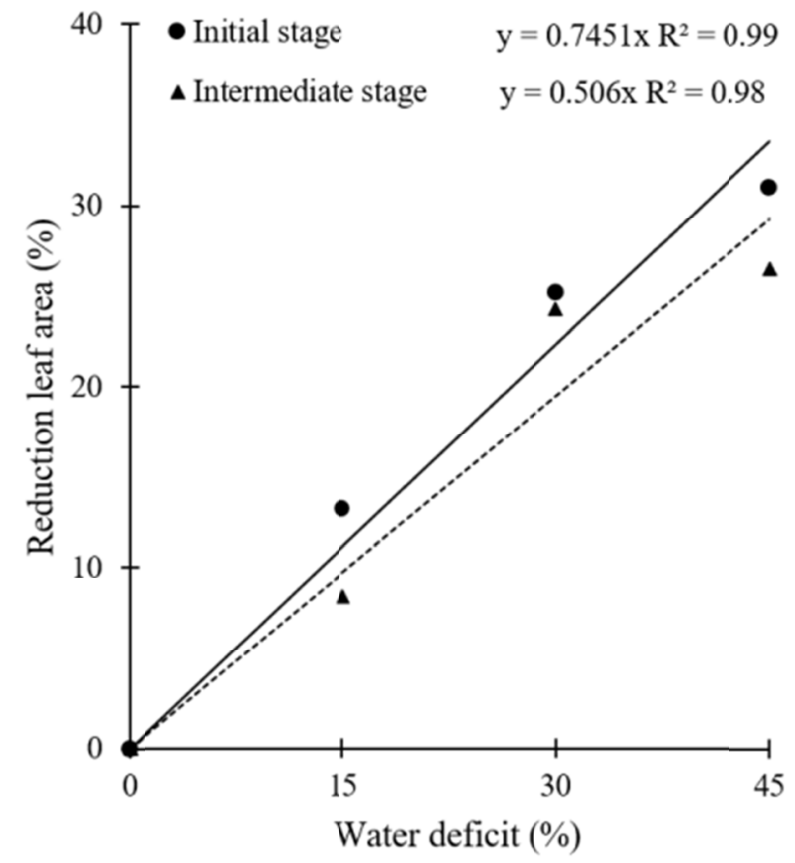

Figure 4. Reduction leaf area in broccoli as a function of water depths for two phenological stages

Çakir (2004) studying the effect of water stress on different stages of corn development verified that during flowering leaf area index values decreased significantly. The decrease in grain yield due to water deficit occurs due to the reduction in leaf expansion, the reduction of the utilization of soil nutrients and the reduction in the photosynthetic area of plants (Chai et al., 2016).

The reduction of leaf area can affect photosynthesis, reducing plant growth (Huang, 2018). It is evident that the water restriction conditions caused the reduction of leaf area as a form of defense and consequently reduction in the production of leaf dry matter (Figure 1). The LDM was also influenced by the phenological stage, and at the final stage $0.080 \mathrm{~kg}$ was obtained being significantly higher than the initial stage $(0.069 \mathrm{~kg})$ and the intermediate stage $(0.071 \mathrm{~kg})$ according to Table 3 .

In the unfolding of the interaction related to leaf area, a significant effect of the stage was obtained for the water depth of 55 and $70 \%$ of the ETc, at the final stage was significantly higher than the initial and intermediate stages. With a deficit of $15 \%$ ( $85 \%$ of the ETc) in the different phenological stages there is no influence on the leaf area of broccoli.

The phenological stage influenced the diameter of broccoli inflorescence, and the intermediate $(0.181 \mathrm{~m})$ and final $(0.184 \mathrm{~m})$ stages were higher than the initial stage $(0.171 \mathrm{~m})$ according to Table 3 . The diameter of broccoli inflorescence was higher when $100 \%$ of the ETc replacement $(0.19 \mathrm{~m})$ was performed, corresponding to an increase of $11 \%$ in relation to the $55 \%$ of the ETc depths (Figure 1). The water deficit at the final stage caused plant height of $0.502 \mathrm{~m}$ it's higher than the initial $(0.490 \mathrm{~m})$ and intermediate $(0.485 \mathrm{~m})$ stages.

The analysis of the influence of controlled water deficit at different phenological stages and levels allows the determination of strategies for water management, increasing productivity efficiency and resource utilization. Sophisticated irrigation management scheduling is required to reduce the amount of supplemental water without a substantial reduction in crop yield. However, more studies must be performed to determine the effects of different water stresses on different plants and different genetic characteristics.

\section{Conclusions}

The water deficit caused greater losses in the productivity of broccoli during the initial and intermediate phenological stages. 
Deficit of $30 \%$ of the ETc at the final stage of the broccoli culture, there was a $7 \%$ drop in productivity, with a drop of $30 \%$ and $23 \%$ in the initial and intermediate stages, respectively.

The RDI response is very dependent on the timing and severity of water deficits. More research is needed to elucidate the basis of the observed responses, given the interactions between water stress and crop yield and quality.

\section{References}

Allen, R. G., Pereira, L. S., Raes, D., \& Smith, M. (1998). Crop evapotranspiration: Guidelines for computing crop water requirements. Irrigation and Drainage Paper 56. Rome: FAO.

Ayas, S. H., Orta, H., \& Yazgan, S. (2011). Deficit irrigation effects on broccoli (Brassica oleracea L. var. Monet) yield in unheated greenhouse condition. Bulgarian Journal of Agricultural Science, 17(4), 551-559.

Çakir, R. (2004). Effect of water stress at different development stages on vegetative and reproductive growth of corn. Field Crops Research, 89, 1-16. https://doi.org/10.1016/j.fcr.2004.01.005

Carvalho, J. A., Santana, M. J., Pereira, G. M., Pereira, J. R. D., \& Queiroz, T. M. (2004). Níveis de déficit hídrico em diferentes estádios fenológicos da cultura da berinjela (Solanum melongena L.). Revista Engenharia Agrícola, 24, 320-327. https://doi.org/10.1590/S0100-69162004000200010

Chai, Q., Gan, Y., Turner, N. C., Zhang, R., Yang, C., Niu, Y., \& Siddique, K. H. M. (2014). Water-saving innovations in Chinese agriculture. Advances in Agronomy, 126, 147-197. https://doi.org/10.1016/B978-012-800132-5.00002-X

Chai, Q., Gan, Y., Zhao, C., Xu, H., Waskom, R. M., Niu, Y., \& Siddique, K. H. M. (2016). Regulated deficit irrigation for crop production under drought stress. A review. Agronomy for Sustainable Development, 36(3). https://doi.org/10.1007/s13593-015-0338-6

Cortés, C. F., Olalla, F. M. S., \& Urrea R. L. (2003). Production of garlic (Allium sativum L.) under controlled deficit irrigation in a semi-arid climate. Agricultural Water Management, 59, 155-167. https://doi.org/ 10.1016/S0378-3774(02)00125-7

Du, T., Kang, S., Zhang, J., \& Davies, W. (2015). Deficit irrigation and sustainable water-resource strategies in agriculture for China's food security. Journal of Experimental Botany, 66, 2253-2269. https://doi.org/ $10.1093 / \mathrm{j} x \mathrm{~b} / \mathrm{erv} 034$

Erdem, Y., Arin, L., Erdem, T., Polat, S., Deveci, M., Okursoy, H., \& Gültaş, H. (2010). Crop water stress index for assesseing irrigation scheduling of drip irrigated broccoli (Brassica oleracea L. var. italica). Agricultural Water Management, 98, 148-156. https://doi.org/10.1016/j.agwat.2010.08.013

Fabeiro, C., Olalla, F. M. S., \& De Juan J. A. (2002). Production of muskmelon (Cucumis melon L.) under controlled deficit irrigation in a semi-arid climate. Agricultural Water Management, 54, 93-105. https://doi.org/10.1016/S0378-3774(01)00151-2

Ferreira, D. F. (2019). Sisvar: A computer analysis system to fixed effects split plot type designs. Revista Brasileira de Biometria, 37, 529-535. https://doi.org/10.28951/rbb.v37i4.450

Gava, R., Frizzone, J. A., Snyder, R. L., Almeida, B. M., Freitas, P. S. L., \& Rezende, R. (2016). Estratégias de manejo de déficit hídrico na irrigação da cultura da soja. Brazilian Journal of Biosystems Engineering, 10, 305-315. https://doi.org/10.18011/bioeng2016v10n3p305-315

Hachmann, T. L., Rezende, R., Pintro, P. T. M., Saath, R., Anjo, F. A., \& Menezes, C. S. L. (2019). Yield, antioxidant activity and shelf-life of cauliflower inflorescences under drought stress and foliar spraying of selenium. Ciência e Agrotecnologia, 43, e017819. https://doi.org/10.1590/1413-7054201943017819

Huang, R. D. (2018). Research progress on plant tolerance to soil salinity and alkalinity in sorghum. Journal of Integrative Agriculture, 17, 739-746. https://doi.org/10.1016/S2095-3119(17)61728-3

Kumari, A., Patel, N., \& Mishura, A. K. (2018). Response of drip irrigated Broccoli (Brassica oleracea var. italica) in different irrigation levels and frequencies at field level. Journal of Applied and Natural Science, 10(1), 12-16. https://doi.org/10.31018/jans.v10i1.1570

Kuşçu, H., Turhan, A., \& Demir, A. (2014). O. The response of processing tomato to deficit irrigation at various phenological stages in a sub-humid environment. Agricultural Water Management, 133, 92-103. https://doi.org/10.1016/j.agwat.2013.11.008 
Miorini, T. J. J., Saad, J. C. C., \& Menegale, M. L. (2011). Supressão de água em diferentes fases fenológicas do feijoeiro. Irriga, 16, 360-368. https://doi.org/10.15809/irriga.2011v16n4p360

Nawaz, F., Ahmad, R., Ashraf, M. Y., Waraich, E. A., \& Khan, S. Z. (2015). Ecotoxicology and Environmental Safety Effect of selenium foliar spray on physiological and biochemical processes and chemical constituents of wheat under drought stress. Ecotoxicology and Environmental Safety, 113, 191-200. https://doi.org/10.1016/j.ecoenv.2014.12.003

Nitsche, P. R., Caramori, P. H., Ricce, W. S., \& Pinto, L. F. D. (2019). Atlas Climático do Estado do Paraná. Londrina, PR: IAPAR.

Nora, L., Dalmazo, G. O., Nora, F. R., \& Rombaldi, C. V. (2012). Controlled water stress to improve fruit and vegetable postharvest quality. Water Stress, $s / v, 59-72$. https://doi.org/10.5772/30182

Pauletti, V., \& Motta, A. C. V. (2017). Manual de adubação e calagem para o estado do Paraná. SBCS/Nepar.

Rodrigues, R. R., Pizetta, S. C., Hott, M. O., Reis, E. F., \& Teixeira, A. G. (2013). Desenvolvimento inicial de brócolis em diferentes disponibilidades hídricas. Enciclopédia Biosfera, 9, 10-41.

Santos, G. O., Vanzela, L. S., \& Faria, R. T. (2018a). Manejo da água na agricultura irrigada (Vol. 1, No. 1, Boletim técnico).

Santos, H. G., Jacomine, P. K. T., Anjos, L. H. C., Oliveira, V. Á., Lumbreras, J. F., Coelho, M. R., ... Cunha, T. J. F. (2018b). Sistema brasileiro de classificação de solos (5th ed.). Embrapa, Brazil.

Schiavon, A., Blind, A. D., Eckstein, B., Pinheiro, J. B., Vendrame, L. P. C., Hanashiro, M. M., ... Melo, R. A. C. (2015). A cultura dos Brócolis (74th ed.). Brasília: Embrapa Informação Tecnológica.

Silva, P. A., Biscaro, G. A., Oliveira, G. Q., Schwerz, F., \& Drehmer, K. K. B. (2019). Fertirrigação com nitrogênio na cultura do brócolis. Engenharia na Agricultura, 27, 472-480. https://doi.org/10.13083/ reveng.v27i5.979

Silveira, A. L., Santana, M. J., Camargos, A. E. V., \& Souza Júnior, M. N. (2016). Reposição de água no solo em diferentes estádios fenológicos da cultura do brócolis. Nucleus, 13, 191-198. https://doi.org/10.3738/ 1982.2278.1610

Taiz, L., Zeiger, E., Moller, I. M., \& Murphy, A. (2017). Fisiologia e desenvolvimento vegetal (6th ed.). Porto Alegre: Artmed.

Tangune, B. F., Pereira, G. M., Sousa, R. J., \& Gatto, R. F. (2016). Produção de brócolis irrigado por gotejamento, sob diferentes tensões de água no solo. Semina: Ciências Agrárias, 37, 7-16. https://doi.org/ 10.5433/1679-0359.2016v37n1p7

Wenneck, G. S., Saath, R., Rezende, R., Andrean, A. F. B. A., \& Santi, D. C. (2021). Resposta agronômica de couve-flor à adição de silício ao solo sob estresse hídrico. Pesquisa Agropecuária Tropical, 51, e66908. https://doi.org/10.1590/1983-40632021v5166908

\section{Copyrights}

Copyright for this article is retained by the author(s), with first publication rights granted to the journal.

This is an open-access article distributed under the terms and conditions of the Creative Commons Attribution license (http://creativecommons.org/licenses/by/4.0/). 